\section{Facial Injuries and the Gender Issue: Expressions of Violence in a Metropolitan Region of Northeastern Brazil}

Gigliana Maria Sobral Cavalcante ${ }^{10}$, Ítalo de Macedo Bernardino ${ }^{(\mathbb{D})}$, Lorena Marques da Nóbrega ${ }^{2}{ }^{(-)}$, Raquel Conceição Ferreira ${ }^{10}$, Efigênia Ferreira e Ferreira $^{1}$, Sérgio d'Avila ${ }^{2}$ (D)
'Department of Preventive Dentistry and Public Health, UFMG - Universidade Federal de Minas Gerais, Belo Horizonte, MG, Brazil ${ }^{2}$ Department of Dentistry, UEPB Universidade Estadual da Paraíba, Campina Grande, PB, Brazil

Correspondence: Sérgio d'Avila, Avenida das Baraúnas, n. 351, 58429-500 Campina Grande, PB, Brasil. Tel: +55-83-3315-3326. e-mail: davila2407@hotmail.com

Key Words: violence, gender and health, maxillofacial injuries.

\section{Introduction}

Violence has been consolidating as one of the most serious problems of contemporary society and is manifested in the most varied forms, from psychological violence and threat to physical aggression and death $(1,2)$. In Brazil, the estimated prevalence of physical violence throughout life across the country is $16.7 \%$ (3). The violence persists with high rates and gender has been reported to be an important factor of victimization due to interpersonal violence and associated trauma (4). In cities, men and women coexist with similar risk factors, but behavioral characteristics may impose a pattern of victimization by specific violence for each of them (2).

Biological, psychological, cultural and sociological issues can provide explanations for the occurrence of interpersonal violence as well as for different victimization profiles $(2,4)$. Historically, men have been identified as the main aggressors $(2,5)$, which can be explained by the process of socialization and construction of masculine identity, commonly permeated by factors such as power, aggressiveness and virility, facilitating the engagement in episodes of aggression (2).

Considering its multifaceted character, violence can be allocated into different categories and subdivisions, among which gender violence deserves special attention due to the increasing incidence of cases against women $(6,7)$. In gender violence, it is understood that violent actions are produced in contexts and relational spaces (interpersonal), both in the private-family context and in work and public spaces, resulting from the asymmetric relations of power that permeate relations between genders $(8,9)$.

Exposure to violence often results in facial trauma with differentials by gender $(2,4)$. This type of injury is considered one of the most significant aggressions due to the possibility of permanent deformity, aesthetic and functional damage, and to cause emotional consequences that can negatively impact the quality of life and well-being of victims (2).

After a critical literature review, it was found that there are few studies that have proposed to investigate facial trauma and the gender issue among victims of interpersonal violence $(2,4)$. Studies investigating differences in health profiles between men and women are essential and can provide valuable information for the decision-making process and development of public policies (10).

The analysis of data from legal medicine services can contribute to the advancement of scientific knowledge related not only to the pattern of trauma exhibited by victims, but also to the circumstances and contexts in which violence occurs. This allows a differentiated analysis in comparison to the analysis of hospital care data, since, from 
these, it is generally possible to identify the characteristics of victims (such as gender and age) and types of injuries.

In this sense, the present study aimed to describe the profile of men and women victims of violence and to identify factors associated with the severity of facial trauma.

\section{Material and Methods}

This is a retrospective study involving the analysis of cases of facial trauma resulting from interpersonal violence in the metropolitan region of Campina Grande, Paraiba state, located in the Northeastern region of Brazil. The region studied is considered one of the main centers of economic development in the Brazilian hinterland. It has population of 379,871 inhabitants and human development index of 0.72 (11). It is located in the state of Paraiba, whose capital ranks second in the national ranking of cities with the highest violence rates, according to the map of violence, which indicates that from the 1990's, the great Brazilian metropolises were no longer engines driving violence, moving to smaller cities in the inner country (12), which shows a context of significant importance.

The study was carried out in accordance with the national and international ethical precepts of research involving human beings and was approved by the Research Ethics Committee (CEP) of the State University of Paraiba (CAAE No. 02266.0.133.000-10). The STROBE (Strengthening the Reporting of Observational Studies in Epidemiology) checklist was used to assist in conducting the research and reporting the results obtained. Data were collected from the 1,704 reports of body injury by aggression of the Institute of Legal Medicine and Dentistry (NUMOL), recorded in 2010, of which 762 records were included in this study, in which the occurrence of facial trauma was observed. This institution is a reference center for 23 municipalities and receives victims of urban, suburban and rural areas. In addition, this institute is the only one that performs corpus delicti examinations in victims of violence in the above metropolitan region and, therefore, the authors consider that the information obtained from it is representative of the reality experienced by the population.

The inclusion criteria were confirmed cases of patients with facial injuries resulting from interpersonal violence, without restriction of gender or age group. There were no exclusion criteria. No cases identified during the period from January to December 2010 were excluded from the analysis, characterizing a census of morbidity cases. The year 2010 was chosen for study because it was the same year that the Brazilian Institute of Geography and Statistics (IBGE) carried out the demographic census, making it possible to better measure the occurrence of violence and injuries in the population context.
All victims reporting being assaulted on police stations are referred to the corpus delicti examination at the institute. Data were collected in the NUMOL archive sector using a form specifically designed for this research based on information available on reports, which included the sociodemographic data of victims (gender, age group, marital status, education level), characteristics of aggressors (gender, relationship between aggressor and victim), circumstances of violence (type, mechanism used), and characteristics of facial trauma. Three researchers carried out collection after a training period in which the adopted classifications were discussed and understood. In the pilot study, three researchers underwent training and calibration exercises. The exercise was performed with 30 different reports randomly selected from the year 2009 on two occasions, with a 1-week interval. Intra-examiner and interexaminer concordances were evaluated using the Kappa test and both obtained $\mathrm{K}=0.85-0.90$, considered good.

In order to investigate the type of violence, the classification of the World Health Organization (13) was used, which defines community violence as violence between individuals who do not have a relation of kinship and who may or may not know each other and intra-family violence as that performed by an intimate partner or family member. The mechanism used in aggression corresponded to the instruments used by the aggressor against the victim, classified as nude aggressions, being considered as those performed by the aggressor's own body (kicks, pushes, slaps); and instrumentalized, with the use of firearm, white weapon or other instruments, such as poles and stones. Regarding the type of injury, bone fractures and lesions in soft tissues stood out, including lacerations, abrasions and loss of substance. Injuries involving teeth and supporting tissues (dentoalveolar injuries) were grouped with bone fractures during data analysis, characterizing lesions of greater severity.

Initially, descriptive statistical analysis was carried out aiming to characterize the sample. Absolute percent frequencies were calculated for qualitative variables, as well as measures of central tendency and variability for quantitative variables. Subsequently, Pearson's chi-square test was used to identify significant differences between genders, age range, marital status, schooling, aggressor's characteristics, circumstances of violence, and facial trauma. To determine factors associated with the severity of facial trauma and to determine if the victim's gender actually exerts influence on the outcome variable, a logistic regression model was constructed with the entry of the following block variables (14): (i) sociodemographic characteristics; (ii) characteristics of aggressors; (iii) circumstances of violence.

In each block, the stepwise backward method was 
used to select variables with $p$ value $<0.20$ in the bivariate analysis, as well as variables considered relevant from the epidemiological point of view. The crude odds ratio (OR) was calculated for the bivariate analysis and the adjusted $O R$ was calculated for the multivariate analysis. Variables with $p$-value $<0.05$ in the adjusted analysis were maintained in the final regression model (14). Possible interaction effects between victim's gender and the other covariates were also tested. Regression models were adjusted considering the total of the sample (men and women), instead of stratifying by gender. This approach increases the power of statistical tests, making it possible to assess if the frequencies of outcomes significantly differ between men and women, as well as to estimate the magnitude of this difference (15).

In order to verify the goodness-of-fit of the final model, the tests most used in literature for this purpose were used, namely: the Omnibus test to verify the hypothesis that the coefficients of the regression model are null; the pseudo coefficients of determination (pseudo-R2) of Cox $\&$ Snell and Nagelkerke, useful for evaluating the overall performance of the regression model; and the Hosmer and Lemeshow test, which compares if predicted values are not significantly different from those observed (15). In addition, the percentage of correct classification of cases to measure the validity of results obtained through logistic regression was also estimated. All analyses were performed using the IBM SPSS Statistics version 20.0 software and considering 95\% confidence interval.

\section{Results}

During the study period, 762 victims presented some type of facial trauma due to violence. All cases occurred in 2010 and victims were examined the same year. Table 1 shows the distribution of cases of facial injuries between genders according to age, marital status, schooling, characteristics of aggressors, circumstances of violence and facial trauma. The mean age of victims was 29.78 years $(S D=13.33$, minimum value $=1.00$, maximum value $=90.00$ ) and the majority were female $(n=408,53.5 \%)$. The frequency of facial trauma of greater severity, such as bone or dentoalveolar fractures, was 7.1\% $(n=54)$. Table 2 shows the cross tabulation between severity of facial trauma, victim's gender and other factors investigated. The occurrence of facial trauma of greater severity was significantly higher among men (11.0\%) compared to women (3.7\%). In addition, que frequency was also higher among victims of violence perpetrated by strange person ( $n=17 ; 10.0 \%)$, in community contexts $(n=46 ; 8.0 \%)$ using instruments ( $n=21 ; 24.4 \%)$.

Table 3 presents the results of logistic regression analysis for facial trauma (fractures compared to soft tissue injury) according to gender and other factors investigated. In the bivariate analysis, factors associated with the occurrence of fractures were victim's gender $(p<0.05)$, aggressor's gender

Table 1. Distribution of cases according to sociodemographic characteristics, circumstances of violence and type of facial trauma

\begin{tabular}{|c|c|c|}
\hline Variables & $\mathrm{n}$ & $\%$ \\
\hline \multicolumn{3}{|l|}{ Victim's gender [762] } \\
\hline Female & 408 & 53.5 \\
\hline Male & 354 & 46.5 \\
\hline \multicolumn{3}{|l|}{ Victim's age group [748] } \\
\hline$\leq 9$ years & 15 & 2.0 \\
\hline $10-19$ years & 141 & 18.9 \\
\hline 20-29 years & 290 & 38.8 \\
\hline 30-39 years & 151 & 20.2 \\
\hline $40-49$ years & 94 & 12.6 \\
\hline $50-59$ years & 32 & 4.3 \\
\hline$\geq 60$ years & 25 & 3.3 \\
\hline \multicolumn{3}{|l|}{ Victim's marital status [738] } \\
\hline Single, widowed or separated & 474 & 64.2 \\
\hline Married or stable union & 264 & 35.8 \\
\hline \multicolumn{3}{|l|}{ Victim's schooling level [602] } \\
\hline Illiterate & 45 & 7.5 \\
\hline$\leq 4$ years of study & 291 & 48.3 \\
\hline 5-8 years of study & 68 & 11.3 \\
\hline 9-11 years of study & 142 & 23.6 \\
\hline$\geq 12$ years of study & 56 & 9.3 \\
\hline \multicolumn{3}{|l|}{ Aggressor's gender [724] } \\
\hline Female & 182 & 25.1 \\
\hline Male & 526 & 72.7 \\
\hline Both & 16 & 2.2 \\
\hline \multicolumn{3}{|c|}{ Relation between aggressor and victim [728] } \\
\hline Partner & 108 & 14.8 \\
\hline Ex-partner & 72 & 9.9 \\
\hline Family & 72 & 9.9 \\
\hline Known person & 306 & 42.0 \\
\hline Strange person & 170 & 23.4 \\
\hline \multicolumn{3}{|l|}{ Type of violence [734] } \\
\hline Intra-family violence & 162 & 22.1 \\
\hline Community violence & 572 & 77.9 \\
\hline \multicolumn{3}{|l|}{ Mechanism of aggression [701] } \\
\hline Aggression using physical force & 635 & 90.6 \\
\hline Aggression using instruments & 39 & 5.6 \\
\hline Mixed aggression & 27 & 3.9 \\
\hline \multicolumn{3}{|l|}{ Type of maxillofacial trauma [762] } \\
\hline Soft tissue injury & 708 & 92.9 \\
\hline Dentoalveolar fracture & 22 & 2.9 \\
\hline Bone fracture & 32 & 4.2 \\
\hline
\end{tabular}

Note. Values between [ ] indicate the total number of valid cases for each variable. 
Table 2. Crosstabulation between facial trauma severity, victim's gender and other factors investigated

\begin{tabular}{|c|c|c|c|c|c|c|c|}
\hline \multirow{3}{*}{ Independent variables } & \multicolumn{4}{|c|}{ Facial trauma } & \multirow{2}{*}{\multicolumn{2}{|c|}{ Total }} & \multirow{3}{*}{$\mathrm{p}$ value } \\
\hline & \multicolumn{2}{|c|}{ Fracture } & \multicolumn{2}{|c|}{ Soft tissue injuries } & & & \\
\hline & $\mathrm{n}$ & $\%$ & $\mathrm{n}$ & $\%$ & $\mathrm{n}$ & $\%$ & \\
\hline Victim's gender & & & & & & & $<0.001^{*}$ \\
\hline Female & 15 & 3.7 & 393 & 96.3 & 408 & 100.0 & \\
\hline Male & 39 & 11.0 & 315 & 89.0 & 354 & 100.0 & \\
\hline Victim's age group & & & & & & & 0.095 \\
\hline$\leq 9$ years & 1 & 6.7 & 14 & 93.3 & 15 & 100.0 & \\
\hline $10-19$ years & 7 & 5.0 & 134 & 95.0 & 141 & 100.0 & \\
\hline 20-29 years & 17 & 5.9 & 273 & 94.1 & 290 & 100.0 & \\
\hline 30-39 years & 9 & 6.0 & 142 & 94.0 & 151 & 100.0 & \\
\hline $40-49$ years & 12 & 12.8 & 82 & 87.2 & 94 & 100.0 & \\
\hline 50-59 years & 5 & 15.6 & 27 & 84.4 & 32 & 100.0 & \\
\hline$\geq 60$ years & 3 & 12.0 & 22 & 88.0 & 25 & 100.0 & \\
\hline Victim's marital status & & & & & & & 0.308 \\
\hline Single, widowed or separated & 30 & 6.3 & 444 & 93.7 & 474 & 100.0 & \\
\hline Married or stable union & 22 & 8.3 & 242 & 91.7 & 264 & 100.0 & \\
\hline Victim's schooling level & & & & & & & 0.943 \\
\hline Illiterate & 4 & 8.9 & 41 & 91.1 & 45 & 100.0 & \\
\hline$\leq 4$ years of study & 18 & 6.2 & 273 & 93.8 & 291 & 100.0 & \\
\hline $5-8$ years of study & 5 & 7.4 & 63 & 92.6 & 68 & 100.0 & \\
\hline 9-11 years of study & 8 & 5.6 & 134 & 94.4 & 142 & 100.0 & \\
\hline$\geq 12$ years of study & 4 & 7.1 & 52 & 92.9 & 56 & 100.0 & \\
\hline Aggressor's gender & & & & & & & 0.067 \\
\hline Female & 6 & 3.3 & 176 & 96.7 & 182 & 100.0 & \\
\hline Male & 42 & 8.0 & 484 & 92.0 & 526 & 100.0 & \\
\hline Both & 2 & 12.5 & 14 & 87.5 & 16 & 100.0 & \\
\hline Relation between aggressor and victim & & & & & & & $0.044^{*}$ \\
\hline Partner & 5 & 4.6 & 103 & 95.4 & 108 & 100.0 & \\
\hline Ex-partner & 2 & 2.8 & 70 & 97.2 & 72 & 100.0 & \\
\hline Family & 1 & 1.4 & 71 & 98.6 & 72 & 100.0 & \\
\hline Known person & 26 & 8.5 & 280 & 91.5 & 306 & 100.0 & \\
\hline Strange person & 17 & 10.0 & 153 & 90.0 & 170 & 100.0 & \\
\hline Type of violence & & & & & & & $0.029^{*}$ \\
\hline Intra-family violence & 5 & 3.1 & 157 & 96.9 & 162 & 100.0 & \\
\hline Community violence & 46 & 8.0 & 526 & 92.0 & 572 & 100.0 & \\
\hline Mechanism of aggression & & & & & & & $<0.001^{*}$ \\
\hline Aggression using physical force & 28 & 4.4 & 607 & 95.6 & 635 & 100.0 & \\
\hline Aggression using instruments & 21 & 24.4 & 65 & 75.6 & 86 & 100.0 & \\
\hline Mixed aggression & 5 & 18.5 & 22 & 81.5 & 27 & 100.0 & \\
\hline
\end{tabular}

*Statistically significant association at 5\% level $(p<0.05)$. 
$(p<0.05)$, type of violence $(p<0.05)$ and mechanism used factors that remained associated with the occurrence of $(p<0.05)$. Based on the final logistic regression model, the fractures were victim's gender $(p<0.05)$, aggressor's gender

Table 3. Logistic regression analysis for severity of facial trauma (bone fractures compared to soft tissue injuries) according to gender and other investigated factors

\begin{tabular}{|c|c|c|c|c|}
\hline \multirow{2}{*}{ Variables } & \multicolumn{2}{|c|}{ Bivariate Analysis } & \multicolumn{2}{|c|}{ Multivariate Analysis } \\
\hline & OR $\mathrm{R}_{\text {Non-adjusted }}(\mathrm{CI}$ 95\%) & $\mathrm{p}$ value & $\mathrm{OR}_{\text {Adjusted }}+$ (CI 95\%) & p-value \\
\hline \multicolumn{5}{|c|}{ Victims’s sociodemographic characteristics (Block 1) } \\
\hline \multicolumn{5}{|l|}{ Victims's gender } \\
\hline Female & 1.00 & & 1.00 & \\
\hline Male & $3.24(1.76-5.99)$ & $<0.001^{*}$ & $2.22(1.08-4.57)$ & $0.030^{*}$ \\
\hline \multicolumn{5}{|l|}{ Victim's age group } \\
\hline$\leq 9$ years & 1.00 & & - & - \\
\hline $10-19$ years & $0.73(0.08-6.38)$ & 0.777 & - & - \\
\hline $20-29$ years & $0.87(0.11-7.03)$ & 0.897 & - & - \\
\hline 30-39 years & $0.89(0.10-7.52)$ & 0.913 & - & - \\
\hline $40-49$ years & $2.05(0.25-17.02)$ & 0.507 & - & - \\
\hline 50-59 years & $2.59(0.28-24.40)$ & 0.405 & - & - \\
\hline$\geq 60$ years & $1.91(0.18-20.22)$ & 0.591 & - & - \\
\hline \multicolumn{5}{|l|}{ Victim's marital status } \\
\hline Single, widowed or separated & 1.00 & & - & - \\
\hline Married or stable union & $1.35(0.76-2.38)$ & 0.309 & - & - \\
\hline \multicolumn{5}{|l|}{ Victim's schooling level } \\
\hline Illiterate & 1.00 & & - & - \\
\hline$\leq 4$ years of study & $0.68(0.22-2.10)$ & 0.498 & - & - \\
\hline 5-8 years of study & $0.81(0.21-3.21)$ & 0.768 & - & - \\
\hline $9-11$ years of study & $0.61(0.18-2.14)$ & 0.441 & - & - \\
\hline$\geq 12$ years of study & $0.79(0.19-3.34)$ & 0.747 & - & - \\
\hline \multicolumn{5}{|l|}{ Aggressor's characteristics (Block 2) } \\
\hline \multicolumn{5}{|l|}{ Aggressor's gender } \\
\hline Female & 1.00 & & 1.00 & \\
\hline Male & $2.55(1.06-6.09)$ & $0.036^{*}$ & $4.88(1.12-21.26)$ & $0.035^{*}$ \\
\hline Both & $4.19(0.77-22.72)$ & 0.097 & $7.20(0.84-61.87)$ & 0.072 \\
\hline \multicolumn{5}{|c|}{ Relation between aggressor and victim } \\
\hline Partner & 1.00 & & - & - \\
\hline Ex-partner & $0.59(0.11-3.12)$ & 0.533 & - & - \\
\hline Family & $0.29(0.03-2.54)$ & 0.263 & - & - \\
\hline Known person & $1.91(0.72-5.11)$ & 0.196 & - & - \\
\hline Strange person & $2.29(0.82-6.40)$ & 0.114 & - & - \\
\hline \multicolumn{5}{|l|}{ Circumstances of violence (Block 3) } \\
\hline \multicolumn{5}{|l|}{ Type of violence } \\
\hline Intra-family violence & 1.00 & & - & - \\
\hline Community violence & $2.75(1.07-7.03)$ & $0.035^{*}$ & - & - \\
\hline \multicolumn{5}{|l|}{ Mechanism of aggression } \\
\hline Aggression using physical force & 1.00 & & 1.00 & \\
\hline Aggression using instruments & $9.63(4.42-20.98)$ & $<0.001^{*}$ & $6.67(2.85-15.60)$ & $<0.001^{*}$ \\
\hline Mixed aggression & $4.93(1.74-13.97)$ & $0.003^{*}$ & $4.34(1.44-13.02)$ & $0.009^{*}$ \\
\hline
\end{tabular}

OR: odds ratio; 95\% CI: 95\% confidence interval. * $\mathrm{p}<0.05$. † Logistic regression: Block 1 adjusted for gender and sociodemographic characteristics of victims; Block 2 adjusted for gender, sociodemographic characteristics of victims and characteristics of aggressors; Block 3 adjusted for gender, sociodemographic characteristics of victims, characteristics of aggressors and circumstances of violence. OR: odds ratio; 95\% CI: 95\% confidence interval. + Wald test. (a) Statistically significant effect at 5\% level $(\mathrm{p}<0.05)$. (b) Undetermined due to very low frequency of occurrence. 
$(p<0.05)$ and mechanism used $(p<0.05)$. Male individuals $(\mathrm{OR}=2.22,95 \% \mathrm{Cl}=1.08-4.57, \mathrm{p}=0.030)$, assaulted by other males (OR=4.88, 95\% $\mathrm{Cl}=1.12-21.26 ; \mathrm{p}=0.035)$ through instrumentalized $(\mathrm{OR}=6.67,95 \% \mathrm{Cl}=2.85-15.60$,

Table 4. Main effect of victim's gender on the pattern of facial trauma and effects of interaction between victim's gender and other covariates

\begin{tabular}{|c|c|c|}
\hline Variables & $\begin{array}{c}\text { OR } \\
\text { (CI 95\%) }\end{array}$ & $\mathrm{p}$ valuet \\
\hline \multicolumn{3}{|l|}{ Main effect } \\
\hline Victim's gender & $3.24(1.76-5.99)$ & $<0.001$ (a) \\
\hline \multicolumn{3}{|l|}{ Interaction effects } \\
\hline Victim's gender *Victim's age group & & $0.001(\mathrm{a})$ \\
\hline Male ${ }^{*} \leq 9$ years & 1 & \\
\hline Male *10-19 years & $2.25(0.79-6.42)$ & \\
\hline Male *20-29 years & $3.03(1.40-6.54)$ & \\
\hline Male *30-39 years & $2.89(1.08-7.77)$ & \\
\hline Male *40-49 years & $5.74(2.28-14.42)$ & \\
\hline Male *50-59 years & $6.24(1.87-20.83)$ & \\
\hline Male $^{*} \geq 60$ years & $5.69(1.47-21.92)$ & \\
\hline Victim's gender *Victim's marital status & & $0.008(a)$ \\
\hline Male *Single, widowed or separated & 1 & \\
\hline Male *Married or stable union & $2.33(1.25-4.34)$ & \\
\hline Victim's gender *Victim's schooling level & & 0.341 \\
\hline Male * Illiterate & 1 & \\
\hline Male $^{*} \leq 4$ years of study & $2.11(0.97-4.59)$ & \\
\hline Male * 5-8 years of study & $2.37(0.75-7.51)$ & \\
\hline Male * 9-11 years of study & $1.58(0.56-4.46)$ & \\
\hline Male * $\geq 12$ years of study & $1.50(0.33-6.85)$ & \\
\hline Victim's gender *Aggressor's gender & & $0.001(\mathrm{a})$ \\
\hline Male * Female & 1 & \\
\hline Male * Male & $3.31(1.78-6.13)$ & \\
\hline Male * Both & $5.15(0.57-46.68)$ & \\
\hline $\begin{array}{l}\text { Victim's gender *Relationship } \\
\text { between aggressor and victim }\end{array}$ & & 0.004(a) \\
\hline Male *Partner & 1 & \\
\hline Male *Ex-partner(b) & - & \\
\hline Male * Family & $0.98(0.12-7.69)$ & \\
\hline Male * Known person & $3.69(1.84-7.40)$ & \\
\hline Male * Strange person & $2.89(1.39-6.02)$ & \\
\hline Victim's gender *Type of violence & & $<0.001$ (a) \\
\hline Male *Intra-family violence & 1 & \\
\hline Male *Community violence & $3.69(1.98-6.88)$ & \\
\hline Victim's gender *Mechanism of aggression & & $<0.001$ (a) \\
\hline Male *Aggression using physical force & 1 & \\
\hline Male *Aggression using instruments & $19.32(8.18-45.60)$ & \\
\hline Male *Mixed aggression & $10.24(3.33-31.48)$ & \\
\hline
\end{tabular}

OR: odds ratio; 95\% CI: 95\% confidence interval. + Wald test. (a) Statistically significant effect at $5 \%$ level $(\mathrm{p}<0.05)$. ${ }^{(b)}$ Undetermined due to very low frequency of occurrence. $\mathrm{p}<0.001)$ or mixed aggressions $(\mathrm{OR}=4.34,95 \% \mathrm{Cl}=1.44$ 13.02; $p=0.009$ ) were more likely to exhibit facial bones or dentoalveolar fractures. In general, the results indicate that the sample size $(n=762)$ was sufficient to generate statistically reliable results, with statistical power $(1-\beta)$ greater than $80.0 \%$ being observed for almost all comparisons using the Epidat version 4.1 software (Pan American Health Organization).

Table 4 shows the evaluation of the main effect of the victim's gender when testing its association with the severity of facial trauma, as well as the statistical significance of the terms of interaction between victim's gender and the other covariates. Victim's gender had a significant main effect $(p<0.001)$ and all terms of interaction, except for the term that included the victim's gender and age group, were also significant $(p<0.05)$. The Omnibus test showed chi-square of 41,837 , with statistical significance $(p<0.001)$, signaling that the predictive variables contribute to improve the quality of predictions about the study outcome. The Cox \& Snell and Nagelkerke pseudo-R2 values were, respectively, 0.060 and 0.159 . The Hosmer and Lemeshow test results showed chi-square of 2.352, with no statistical significance $(p=0.671)$, indicating that the predicted values are not significantly different from those observed. The percentage of correct classification of cases was $93.7 \%$, suggesting good fit of the regression model and confirming the validity of the results obtained.

\section{Discussion}

The results showed important differences in victimization due to interpersonal violence and facial trauma according to gender, indicating a greater severity of violence for the male gender. These findings are consistent with those observed in another study conducted in Belo Horizonte (2). Young adult males are generally the main victims of interpersonal violence (2). This can be explained considering the process of socialization and construction of masculine identity, which is often characterized by factors 
such as power, strength, and aggressiveness, capable of increasing the probability of engaging in violent events (2).

Examining men's experiences with formal help seeking is especially crucial in the light of the studies that find many men are also victims of IPV (14). A study in Canada, revealed four major types of IPV victimization among men that ranged from milder forms of physical violence (57.3\%) to extremely severe physical IPV combined with psychological abuse (9.7\%) (16). Qualitative studies found that male victims of IPV reported feelings of vulnerability, shame, powerlessness, and fear of being seen "weak," "unmasculine," or "unmanly" $(17,18)$.

Mulawa et al. (19), understudy in Tanzania, observed that $34.8 \%$ of men and $35.8 \%$ of women reported any form of IPV victimization. Men and women also reported a similar prevalence of psychological and sexual victimization. However, more women reported physical IPV victimization than men.

The logistic regression model revealed that men were more likely to exhibit facial bones or dentoalveolar fractures when compared to women, which is in line with the results observed by other authors $(2,20)$. Injuries of this type are considered more serious and may result in permanent aesthetic and functional deformities, requiring complex surgical procedures for the rehabilitation and reintegration of the individual into society $(2,21)$.

Data also showed that men were generally more likely to suffer instrumental attacks by other men. The occurrence of facial trauma resulting from assaults by firearm and white weapon is worrisome, considering the potential of deformity, disfiguration and lethality of these instruments.

Data from the latest study by the Brazilian Institute of Geography and Statistics (IBGE) on the characteristics of victimization and access to justice in the country emphasized that, despite the fact that physical aggression against males surpasses females, the results compared to the 1998 survey show an increase in the participation of women as victims of physical aggression (22).

Another study performed in Portugal (23) addressing physical aggression against children and adolescents (0 to less than 18 years old) occurred between 2009 and 2013 reported that most subjects evaluated were male adolescents and the most affected body region was the face, to which 747 injuries (24.7\%) were recorded, with statistically significant association between sex and region (head and face). Therefore, dentists should routinely examine the face, neck and skull, which make them the most appropriate health professionals to identify cases of aggression early.

The findings of the present study indicate a greater vulnerability of women to conflicts involving affective ties or consanguineous bonds, suggesting that the expression of interpersonal violence reflects the typically patriarchal hegemonic model of female subordination and male domination. The roles and symbols attributed to gender may explain the differences found regarding the severity of injuries and the mechanism used for face aggression.

Despite numerous efforts to address violence against women in the country, violence rates remain high. In the study of Aguirre et al. (5), related that violence against women (VAW) is widely recognized as a global phenomenon. The vast majority of the women in your sample endured multiple forms of abuse at the hands of multiple perpetrators over the course of many years. Intimate partners and immediate and extended family members together perpetrated the majority of abuses.

It is important to consider that the approval of Federal Law 11.340 / 2006, also known as the Maria da Penha Law, represented a historical milestone in the fight against violence against women, since it recognized this practice as a crime and created mechanisms to restrain it (24). However, violence rates remain high, signaling that the law alone is not enough to prevent violent events from occurring. It is estimated that in Brazil, between 1980 and 2013, 106,093 women were killed, 4,762 only in 2013 (7). The most common type of facial trauma observed in women victims of violence was soft tissue injury. Although this pattern of trauma signals less seriousness, it deserves attention, since it can generate physical and, above all, emotional consequences.

Given the complex nature of intimate relationships and intertwining roles, behaviors, and emotions of both partners in these relationships, examining experiences of both male and female intimate partners can provide a deeper understanding of and new insights into the dynamic of violence between intimate partners (25). To perceive a reduction in the levels of interpersonal violence, it is necessary to recognize male and female identities that represent risk and that public policies should be adopted in order to minimize inequities between genders that perpetuate vulnerability conditions.

Although the present study is original and has been conducted under methodological rigor, it has some limitations. Since it is a study involving the analysis of cases seen in a medical-legal and forensic service, there is the possibility of underreporting. In addition, it was not possible to assess the impact of facial trauma on the quality of life and well-being of victims of violence. Future studies should investigate in greater detail the determinants of the occurrence of violence against women perpetrated by other women.

However, it is important to highlight the quality of information obtained from medical-legal and social records from the Institute of Legal Medicine and Dentistry. 
Due to the fact that Brazilian legislation determines that victims of violence who have suffered some kind of injury, when reporting abuse, are sent to perform corpus delicti examinations in institutions such as this, the authors consider that the study has internal and external validity, and the results obtained are very close to the reality experienced by the population.

This study allowed the investigation of associations between facial trauma, gender and characteristics of interpersonal violence, which constitutes a serious public health problem not only in the Northeastern region of Brazil. The findings highlight that men and women have important victimization differentials in relation to interpersonal violence and patterns of facial trauma. In addition, other authors may replicate the multivariate analysis model used here and investigate the influence of other independent variables on the pattern of facial trauma exhibited by victims of interpersonal violence.

The findings allowed to measure the magnitude of the events in the region studied, generating information to support the creation of prevention programs, awareness of the population, culture of peace, social support and specialized care for victims of violence. The implementation of an integrated and continuous system of epidemiological surveillance related to the occurrence of interpersonal violence in the region studied is encouraged in order to support the decision-making process and evaluate the results of the application of new public health policies.

The results obtained allow us concluding that the victim's gender, the aggressor's gender and the mechanism of aggression are factors that may influence the pattern of facial trauma suffered by victims of violence. The integration of data on victims of violence treated in the primary, secondary and tertiary care services is essential, as well as in medical-legal and forensic services. The recognition of differences in victimization due to violence and gender-based trauma is necessary in order to allocate adequate resources for the expansion of care centers to victims throughout the national territory. Coping with violence requires the active involvement of all levels of political, social, cultural, judicial and health organization.

\section{Resumo}

Os objetivos desta investigação foram descrever o perfil de homens e mulheres vitimas de violência e identificar fatores associados à gravidade do trauma facial. Foi realizado um estudo retrospectivo de 762 prontuários de vítimas atendidas no Instituto de Medicina Legal e Odontologia de uma região metropolitana do Nordeste do Brasil. A variável dependente foi o tipo de trauma facial sofrido pelas vitimas. Variáveis independentes foram as características sociodemográficas das vítimas, características dos agressores e circunstâncias de violência. Estatísticas descritivas, bivariadas (teste $\chi 2$ ) e multivariadas foram feitas por meio de regressão logística. 0 nível de significância foi fixado em $p<0,05$. A idade média das vítimas foi de 29,78 anos ( $D P=13,33$ ). Com base no modelo de regressão final, os indivíduos do sexo masculino [odds ratio $(\mathrm{OR})=2,22$, IC 95\%=1,08-4,57, $\mathrm{p}=0,030]$, agredidos por outros sujeitos do sexo masculino $(\mathrm{OR}=4,88$; IC $95 \%=1,12-21,26 ; p=0,035)$ por meio de instrumentos $(\mathrm{OR}=6,67$; IC $95 \%=2,85-15,60 ; p<0,001)$ ou agressões mistas ( $O R=4,34 ;$ IC $95 \%=1,44-$ $13,02 ; p=0,009)$ foram mais propensos a apresentar fraturas de ossos faciais ou fraturas dentoalveolares. Os achados apontam que homens e mulheres apresentam importantes diferenciais de vitimização em relação à violência interpessoal e trauma facial. 0 gênero da vítima, o gênero do agressor e o mecanismo de agressão podem exercer influência sobre os padrões de trauma facial.

\section{Acknowledgements}

The authors are grateful to the Institute of Legal Medicine and Dentistry, Campina Grande, state of Paraiba, Brazil, for authorizing data acquisition. This work was supported by Conselho Nacional de Desenvolvimento Científico e Tecnológico [grant number 14-2010, MCT/CNPq Universal] and Fundação de Apoio à Pesquisa do Estado da Paraiba [grant number 02-2009, MS/CNPq/FAPESO).

\section{References}

1. Bernardino İM, Barbosa KGN, Nóbrega LM, Cavalcante GMS; Ferreira EF, d'Avila S. Violence against women in different stages of the life cycle in Brazil: an exploratory study. Rev Bras Epidemiol 2016;19:740-752.

2. Silva CJ, Ferreira RC, Paula LP, Haddad JP, Moura AC, Naves MD, et al. Maxillofacial injuries as markers of urban violence: a comparative analysis between the genders. Cien Saude Coletiva 2014;19:127-136.

3. Bott S, Guedes A, Ruiz-Celis AP, Mendoza JA. Intimate partner violence in the Americas: a systematic review and reanalysis of national prevalence estimates. Rev Panam Salud Publica 2019;43:e26.

4. Sousa RI, Bernardino ÍM, Castro RD, Cavalcanti AL, Bento PM, d'Ávila S. Facial trauma as physical violence markers against elderly Brazilians: A comparative analysis between genders. Arch Gerontol Geriatr 2016;67:55-60.

5. Aguirre NG, Milewski AR, Shin J, Ottenheimer D. Gender-based violence experienced by women seeking asylum in the United State: A lifetime of multiple traumas inflicted by multiple perpetrators. J Forensic Leg Med 2020;72:101959.

6. Leite MT, Figueiredo MF, Dias OV, Vieira MA, Souza e Souza LP, Mendes DC. Occurrence of violence against women in different life cycles. Rev Lat-Am Enfermagem 2014;22:85-92.

7. Waiselfisz JJ. Map of violence 2015: homicide of women in Brazil. Rio de Janeiro: FLACSO;2015.

8. Michau L, Horn J, Bank A, Dutt M, Zimmerman C. Prevention of violence against women and girls: lessons from practice. Lancet 2015;385:16721684.

9. Piosiadlo LCM, Fonseca RMGS, Gessner R. Subordination of gender: reflecting on the vulnerability to domestic violence against women. Esc Anna Nery 2014;18:728-733.

10. Vilela W, Monteiro S, Vargas E. The incorporation of new themes and knowledge at public health studies: the gender category case. Cienc Saude Colet 2009;14:997-1006.

11. Brazil. Brazilian Institute of Geography and Statistics. First results of the 2010 census. Rio de Janeiro;2010.

12. Waiselfisz JJ. Map of violence 2012: the new patterns of homicidal violence in Brazil. Rio de Janeiro: Centro Brasileiro de Estudos Latinoamericanos (Cebela);2012.

13. World Health Organization. Word report on violence and health. Geneva;2002.

14. Lysova A, Dim E, Dutton D. Prevalence and consequences of intimate partner violence in Canada as measured by the national victimization survey. Partner Abuse 2019;10:199-221.

15. Hair JF, Black WC, Babin JB, Anderson RE, Tatham RL. Multivariate data analysis. Prentice-Hall: Copyright; 2009.

16. Lysova A, Dim EE. Severity of victimization and formal help seeking among men who experienced intimate partner violence in their ongoing relationships. J Interpers Violence 2020;886260520922352. 
17. Brooks C, Martin S, Broda L, Poudrier J. "How many silences are there?" Men's experience of victimization in intimate partner relationships. J Interpers Violence 2017:886260517719905.

18. Morgan W, Wells M. "It's deemed unmanly": Men's experiences of intimate partner violence (IPV). J Forensic Psychiatry Psychol 2016;27:404-418.

19. Mulawa M, Kajula U, Yamanis TJ, Balvanz P, Kilonzo MN, Maman S. Perpetration and victimization of intimate partner violence among young men and women in Dar es Salaam, Tanzania. J Interpers Violence 2018;33:2486-2511.

20. Brink 0. When violence strikes the head, neck, and face. J Trauma 2009;67:147-151.

21. Wong JY, Choi AW, Fong DY, Wong JK, Lau CL, Kam CW. Patterns, aetiology and risk factors of intimate partner violence-related injuries to head, neck and face in Chinese women. BMC Womens Health
2014;14:1-25.

22. Brazilian Institute of Geography and Statistics. National Household Sample Survey. Characteristics of victimization and access to justice in Brazil. Rio de Janeiro;2010.

23. Vidal HG, Caldas IM, Coelho Júnior LGTM, Souza EHA, Carvalho MVD, Soriano EP, et al. Orofacial injuries in children and adolescents (20092013): a 5-year study in Porto, Portugal. Braz Dent J 2018;29:316-320.

24. Brazil. Law no. 11,340 of August 7, 2006. Diário Oficial da União. Brasilia; 2006

25. Lysova A. Embracing the complexity of partner violence from a violent events perspective. J Fam Viol 2016;31,1005-1008.

Received June 3, 2020 Accepted July 21, 2020 